\title{
New perspectives on active pediculosis detection in schoolchildren from Southern
}

\section{Brazil}

\author{
Novas perspectivas no diagnóstico de pediculose ativa em escolares da região sull do Brasil \\ Nuevas perspectivas sobre la detección de pediculosis activa en escolares del sur de Brasil
}

Bruno Paulo Rodrigues Lustosa ORCID: https://orcid.org/0000-0002-0150-5962 Federal University of Paraná, Brazil E-mail: brunopaulorl@ufpr.br Larissa Reifur

ORCID: https://orcid.org/0000-0003-0536-8915 Federal University of Paraná, Brazil E-mail: reifurla@ufpr.br Juciliane Haidamak

ORCID: https://orcid.org/0000-0003-1100-8908 Federal University of Paraná, Brazil E-mail: jucilianeha@gmail.com

Marielly Ospedal Batista

ORCID: https://orcid.org/0000-0002-4605-6873 Federal University of Paraná, Brazil E-mail: mariellyospeda@gmail.com

Adelino Tchilanda Tchivango ORCID: https://orcid.org/0000-0002-1939-0139 Instituto Superior Politécnico de Malanje, Angola E-mail: adelichi24@gmail.com

Bruna Jacomel Favoreto de Souza Lima ORCID: https://orcid.org/0000-0001-9552-9369 Federal University of Paraná, Brazil E-mail: jacomel.bruna@gmail.com

Camila Yumi Oishi Kampmann ORCID: https://orcid.org/0000-0001-5155-4802 Federal University of Paraná, Brazil E-mail: camioishi@gmail.com

Vania Aparecida Vicente ORCID: https://orcid.org/0000-0002-2953-4861 Federal University of Paraná, Brazil E-mail: vicente@ufpr.br Maria Adela Valero ORCID: https://orcid.org/0000-0003-1584-8330 Universitat de València, Spain E-mail: madela.valero@uv.es

Márcia Kyoie Shimada ORCID: https://orcid.org/0000-0002-4610-5516 Federal University of Paraná, Brazil E-mail: shimada@ufpr.br

Débora do Rocio Klisiowicz

ORCID: https://orcid.org/0000-0002-7699-0763 Federal University of Paraná, Brazil E-mail: deborak@ufpr.br

\begin{abstract}
The present study aims to analyze the prevalence and risk factors of active pediculosis and to compare the efficacy and sensitivity of the vacuum method with the comb method and the visual inspection with a magnifying glass in order to determine the best methodology to detect active pediculosis among schoolchildren from Paraná state. Each child was examined by the three methods in sequence and a playful activity was introduced to increase the children likelihood to participate in the study. Additionally, hair characteristics and other risk factors as sex, age, and area of living were take into consideration to measure epidemiological aspects. From a total of 358 schoolchildren from southern Brazil, overall pediculosis prevalence was $45.5 \%$, while active pediculosis prevalence was $13.1 \%$. Regarding active pediculosis, there was no statistical difference among sex. However, nine-year-old girls were most likely to have active pediculosis. The vacuum method was 5.96 and 11.29 times more efficacious than the magnifying glass method and the comb method,
\end{abstract}


respectively, and also had higher sensitivity (74.5\%) in detecting active pediculosis. When analyzing hair characteristics, children with long and wavy/curly hair were more often diagnosed by the vacuum method than children with short and wavy/curly hair. The vacuum method was the most effective method and proved to be an optimal option to detect active pediculosis among schoolchildren, mostly in children with wavy/curly hair.

Keywords: Pediculus capitis; Lice infestation; Public health; Diagnosis; Child health.

\section{Resumo}

O objetivo do estudo foi avaliar a prevalência e fatores de risco da pediculose ativa entre escolares do Paraná, além disso, foram comparadas a eficácia e a sensibilidade dos métodos da aspiração, pente-fino e inspeção visual com uma lupa dermatológica, a fim de determinar a melhor metodologia de diagnóstico. Cada criança foi examinada pelos três métodos em sequência. Fatores de risco como características do cabelo, sexo, idade e ambiente foram comparados. Além disso, uma atividade lúdica foi introduzida para aumentar a probabilidade das crianças em participar do estudo. Foram examinados um total de 358 escolares do sul do Brasil. A prevalência de pediculose geral foi de 45,5\%, enquanto que a prevalência de pediculose ativa foi de $13,1 \%$. Em relação à pediculose ativa, não houve diferença entre os sexos. Entretanto, meninas de nove anos de idade tiveram maior probabilidade de infestação por pediculose ativa. O método da aspiração foi 5,96 e 11,29 vezes mais eficaz que método da lupa dermatológica e o método do pente-fino, respectivamente, e também obteve maior sensibilidade $(74,5 \%)$ na detecção da pediculose ativa. Ao considerar as características do cabelo, crianças com cabelos longos e ondulados/cacheados foram mais diagnosticadas pelo método da aspiração do que crianças com cabelos curtos e ondulados/cacheados. A aspiração foi a metodologia mais eficaz e provou ser uma ótima opção para detectar pediculose ativa em escolares, principalmente em crianças de cabelo ondulado/cacheado.

Palavras-chave: Pediculus capitis; Infestação por piolhos; Saúde pública; Diagnóstico; Saúde da criança.

\section{Resumen}

El presente estudio tiene como objetivo analizar la prevalencia y factores de riesgo de la pediculosis activa y comparar la eficacia y sensibilidad del método de aspiración con el método del peine y la inspección visual con lupa dermatológica con el fin de determinar la mejor metodología para detectar la pediculosis activa en escolares del estado de Paraná. Cada niño fue examinado por los tres métodos consecutivamente. Se introdujo una actividad lúdica para aumentar la probabilidad de participación de los niños en el estudio. Adicionalmente, se tomaron en consideración las características del cabello y otros factores de riesgo como sexo, edad y estilo de vida para considerar aspectos epidemiológicos. En un total de 358 escolares del sur de Brasil, la prevalencia general de pediculosis fue del $45,5 \%$, mientras que la prevalencia de pediculosis activa fue del $13,1 \%$. Con respecto a la pediculosis activa, no hubo diferencia estadística entre géneros. Las niñas de nueve años mostraron más probabilidades de tener pediculosis activa. El método de la aspiración fue 5,96 y 11,29 veces más eficaz que el método de la lupa dermatológica y el método del peine, respectivamente, alcanzando además una mayor sensibilidad (74,5\%) en la detección de pediculosis activa. Al analizar las características del pelo, los niños con pelo largo y ondulado/rizado fueron diagnosticados con más frecuencia por el método de la aspiración que los niños con pelo corto y ondulado/rizado. El método de la aspiración fue el método más eficaz y demostró ser una óptima opción para detectar la pediculosis activa entre los escolares, principalmente en niños con cabello ondulado/rizado.

Palabras clave: Pediculus capitis; Infestación por piojos; Salud pública; Diagnóstico; Salud infantil.

\section{Introduction}

Pediculosis is the head infestation caused by Pediculus humanus capitis (De Geer, 1778). This ectoparasite can reach almost $40 \%$ of schoolchildren in Brazil, mostly in impoverished neighborhoods (Heukelbach et al., 2005; Pilger et al., 2008; Lustosa et al., 2020). Direct head-to-head contact is the mainly cause of head lice infestation, although, sharing fomites can represent a secondary route of transmission (Cummings et al., 2018). While most infestations are asymptomatic, many schoolchildren suffer from social stigmatization related to the disease's myths and misguidance, leading these children to feel ashamed and hide the infestation from family members and school community (Cunha et al., 2008; Gordon, 2007).

It is recommend the lice comb as the gold standard to diagnose active infestation (De Maeseneer et al., 2000; Mumcuoglu et al., 2001; Jahnke et al., 2009), however, this procedure can be troublesome on children with wavy/curly hair (Mumcuoglu et al. 2020). On the other hand, physicians propose using the visual inspection with a magnifying glass (VIMG) to detect head lice infestation on a harmless way, even though its efficacy to detect a living louse has not been evaluated (Karim et al., 2015).

The use of a vacuum cleaner adapted to catch and hold lice forms from the hair and scalp, associated with playful 
activity, is an effective alternative to detect mobile lice while is able to increase the children's acceptability to the diagnosis (Birkemoe et al,. 2015; Lustosa et al., 2020). However, its comparison with the lice comb and the visual inspection methods still need to be assessed. In this context, the present study aims to compare the accuracy, sensitivity and efficacy of the vacuum method with the comb method and the VIMG, as a diagnostic method of active pediculosis. In addition, risk factors related to pediculosis in schoolchildren from the metropolitan area of Curitiba, on Paraná state, southern Brazil, were assessed in order to help combat the disease.

\section{Methodology}

\subsection{Ethical standards and study area}

This study was approved by the Research Ethical Committee of the Federal University of Paraná (CEP/SD-UFPR) (CAAE 38757614.9.0000.0102), and it is in accordance with the Declaration of Helsinque 1964 and the 466/2012 resolution from the Brazilian National Health Council (NHC).

The study was carried out in three public schools from two municipalities around Curitiba metropolitan area, Colombo

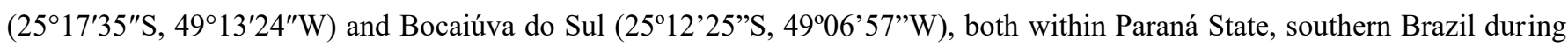
2017 to 2019. Colombo municipality has a Human Development Index (HDI) of 0.733 and about $95 \%$ from its population is located at the urban area. Bocaiúva do Sul has an HDI of 0.640, and half of its population is located on rural areas (Programa das Nações Unidas para o Desenvolvimento, 2013) (Figure 1).

Figure 1. Brazilian map (top) highlighting studies areas and schools within Paraná State.

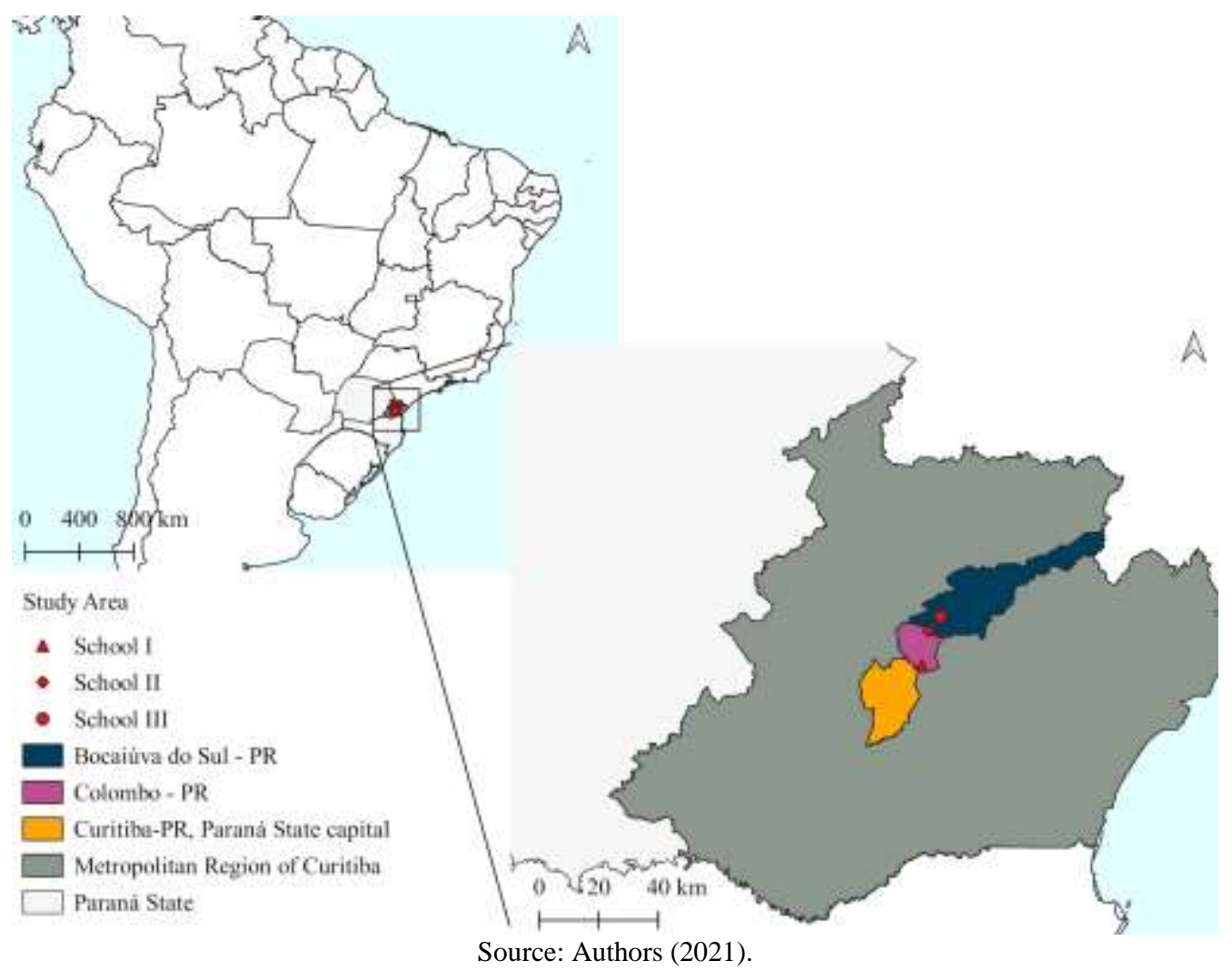

The research was exploratory, descriptive and cross-sectional, conducted using quantitative and qualitative approaches to compare efficacy, sensitivity and accuracy of three different pediculosis diagnosis methods on children of public schools of Parana State, previously described by Mumcuoglu et al. (2001), Jahnke et al. (2009) and Lustosa et al. (2020). 
Two schools from Colombo were selected to the study, one located in the urban area (School I) and another located in the rural area (School II). From Bocaiúva do Sul only one school was selected, however, part of its students lived in urban and part in rural areas (School III - Urban and School III - Rural). The children from the three schools were 4 to 10 years old, whose guardians signed a written informed consent after attending a meeting held with the school community to explain the scope of the project.

\subsection{Head lice assessment}

In this study, the diagnosis was performed by trained examiners, as previously described by Lustosa et al. (2020), and categorized in overall pediculosis, presence of nits, and active pediculosis. Overall pediculosis was determined by entomological evidence collection, including insects clues such nits, ecdysis, louse fragments, nymphs and adult lice, whereas active pediculosis was determined by the presence of mobile lice, such as nymphs and adults, regardless of whether they have presented nits to the hair or any other lice evidence. The presence of nits diagnosis included detection of only nits, or nits associated with any other lice evidence. Nits, viable or nonviable, were always considered as an evidence of past infestation or overall pediculosis (Jahnke et al, 2009).

Children were inspected for pediculosis by three methods conducted in sequence. First they underwent visual inspection with the aid of a magnifying glass (VIMG) (Solver HL-500@ with 5X amplitude). On this method, the examiner systematically parted the child hair with the fingers, separating in four quadrants: neck, behind the ears and top of the head and looked for head lice evidences. After visual inspection, each participant was dry-combed with a head lice comb with metal teeth (Dr Pentinho@). The hair was combed from the scalp to the end of the hair, and the comb was placed in a hermetic plastic bag (17x $12 \mathrm{~cm})$ to be examined on a stereoscope microscope with amplification of 20-40X. After the comb method, a third examiner assessed the child hair with the vacuum method in accordance with Lustosa et al. (2020), in which the child scalp and hair were aspirated by a vacuum cleaner (LAVOR@ $1400 \mathrm{~W}$ ) adapted with a filter to capture $P$. humanus capitis (complementary video showing the vacuum metod: https://youtu.be/DpRIoR3vnas).

Children hair was classified on size, type and color by adapting the method of Borges \& Mendes (2002). Hair length was classified on short $(0-3 \mathrm{~cm})$, medium ( $3 \mathrm{~cm}$ to the top of the shoulders) and long (below the shoulders); type was classified on straight (hair without curves) and wavy/curly (hair with any curve); and color was classified as light (blond or red color) and dark (brown or dark color).

A playful activity named "Power Machine" was used as an inducement to increase children reliability and participation. On this pretend play proposition, the child was informed that "he or she should pass through two tests to determine the ability to receive the super-hero powers from one of many characters stickers placed on the vacuum cleaner". On that way, the magnifying glass was used to "observe the child ability" while the lice comb served to "open the hair follicles to receive the power", and the "vacuum cleaner or Power Machine would give the chosen power" while the child was pressing the vacuum cleaner sticker. After the procedures, all participants positive for pediculosis (active or overall) were referred to a health care unit.

\subsection{Statistical analysis}

Data were analyzed using the statistical software R program (version 3.6.1, R Core Team). A minimum sample size of 225 was determined, by considering twenty thousand schoolchildren in the recruited area (Programa das Nações Unidas para o Desenvolvimento, 2013), a point prevalence of $18 \%$ (Lustosa et al., 2020), and a statistical error of $0.05 \%$, using the "epiDisplay" package (Chongsuvivatwong et al., 2018).

Risk factors to overall pediculosis, nits diagnosis and active pediculosis was calculated using the Odds Ratio test (OR) with a confidence interval of $95 \%$. Differences between proportions were determined using the Chi-square test and the Fisher test, when available. Thus head lice infestation was compared to municipality, area of living, sex, and age. Multivariate analysis 
(ANOVA) was performed to find association between risk factors with the data submitted to a binomial factor using a logistic regression model, and a pairwise analysis was performed using the Tukey's multiple comparison test.

Sensitivity, accuracy and negative predictive value (NPV) of each method to diagnose active pediculosis was calculated by the "epiR" package (Stevenson et al., 2019), while efficacy was calculated by the OR. Since active infestation misdiagnosis is rare by training examiners, the study protocol did not consider any false positive results, thus a $100 \%$ specificity was considered for the three methods (Jahnke et al., 2009). Hair characteristics were evaluated through OR with significant differences calculated as previously informed.

\section{Results}

Head lice examination was conducted in 358 schoolchildren, 4-10 years old, 198 (55.3\%) girls and 160 (44.7\%) boys (Table 1). Regarding area of living, $232(64.8 \%)$ children were from urban areas and $124(34.6 \%)$ were from rural areas, with missing data from two children (Table 1). The results from all three methods revealed $45.5 \%$ children (163/358) with overall pediculosis, while 36.9\% (132/358) were found with nits, and 13.1\% (47/358) were diagnosed with active pediculosis (Table 1).

Table 1. Pediculosis prevalence and risk factors associated to schoolchildren in urban and rural areas from Colombo and Bocaiúva do Sul, Southern Brazil.

\begin{tabular}{|c|c|c|c|c|c|c|}
\hline & \multicolumn{2}{|c|}{ Overall pediculosis } & \multicolumn{2}{|c|}{ Nits detection } & \multicolumn{2}{|c|}{ Active infestation } \\
\hline & $\mathrm{n} / \mathrm{N}(\%)$ & OR & $\mathrm{n} / \mathrm{N}(\%)$ & OR & $\mathrm{n} / \mathrm{N}(\%)$ & OR \\
\hline \multicolumn{7}{|l|}{ MUNICIPALIT } \\
\hline Colombo & $123 / 254(48.4)$ & 1.50 & $97 / 254(38.2)$ & 1.22 & $39 / 254(15.4)$ & $2.18^{*}$ \\
\hline Bocaiúva do Sul & 40/104 (38.5) & 1.00 & $35 / 104$ (33.7) & 1.00 & $8 / 104(7.7)$ & 1.00 \\
\hline \multicolumn{7}{|l|}{$\mathrm{AREA}^{\#}$} \\
\hline Urban & $113 / 232(48.7)$ & 1.41 & $94 / 232(40.5)$ & 1.54 & $31 / 232(13.4)$ & 1.04 \\
\hline Rural & $50 / 124(40.3)$ & 1.00 & $38 / 124(30.6)$ & 1.00 & 16/124 (12.9) & 1.00 \\
\hline \multicolumn{7}{|l|}{ SCHOOL/AREA } \\
\hline School I (Urban) & $85 / 162(52.5)$ & 1.93 & $67 / 162(41.4)$ & 2.20 & $25 / 162(15.4)$ & 2.83 \\
\hline School II (Rural) & $38 / 92(41.3)$ & 1.23 & $30 / 92(32.6)$ & 1.51 & $14 / 92(15.2)$ & 2.78 \\
\hline School III (Urban) & $28 / 71(39.4)$ & 1.14 & $27 / 71(38.0)$ & 1.92 & $6 / 71(8.5)$ & 1.43 \\
\hline School III (Rural) & $12 / 33(36.4)$ & 1.00 & $8 / 33(24.2)$ & 1.00 & $2 / 33(6.1)$ & 1.00 \\
\hline \multicolumn{7}{|l|}{ SEX } \\
\hline Girls & $107 / 198(54.0)$ & $2.18 * *$ & 98/198 (49.5) & $3.63 * *$ & $32 / 198(16.2)$ & $1.86^{*}$ \\
\hline Boys & $56 / 160(35.0)$ & 1.00 & $34 / 160(21.3)$ & 1.00 & $15 / 160(9.4)$ & 1.00 \\
\hline \multicolumn{7}{|l|}{$\operatorname{AGE}(\mathrm{YO})$} \\
\hline 4 & $8 / 20(40.0)$ & 1.00 & $7 / 20(35.0)$ & 0.91 & $2 / 20(10.0)$ & 1.83 \\
\hline 5 & $18 / 35(51.4)$ & 1.59 & $14 / 35(40.0)$ & 1.13 & $7 / 35(20.0)$ & 4.13 \\
\hline 6 & $40 / 83(48.2)$ & 1.40 & $31 / 83$ (37.3) & 1.01 & 16/83 (19.3) & 3.94 \\
\hline 7 & $37 / 94(39.4)$ & 0.97 & $31 / 94(33.0)$ & 0.83 & 7/94 (7.4) & 1.33 \\
\hline 8 & $22 / 56(39.3)$ & 0.97 & 19/56 (33.9) & 0.87 & $5 / 56(8.9)$ & 1.62 \\
\hline 9 & $24 / 35(68.6)$ & $3.27 *$ & $17 / 35(48.6)$ & 1.60 & $8 / 35(22.9)$ & $4.89 *$ \\
\hline 10 & $14 / 35(40.0)$ & 1.00 & $13 / 35(37.1)$ & 1.00 & $2 / 35(5.7)$ & 1.00 \\
\hline Total & $163 / 358(45.5)$ & & $132 / 358(36.9)$ & & $47 / 358(13.1)$ & \\
\hline
\end{tabular}


Note: Overall pediculosis (nits presence, mobile forms and entomological evidences); Nits detection (viable and non-viable nits attached on the hair); active pediculosis (nymphs and adult lice); $\mathrm{YO}=$ years old; $\mathrm{N}=$ number of procedures per variable; $\mathrm{n}=$ number of positive diagnosis; $\%=$ prevalence of pediculosis per variable $(\mathrm{N} / \mathrm{n}) ; \mathrm{OR}=$ Odds Ratio test shows the risk of infestation per variable among the infestation factors; $*=$ p-value non-significant among 0,1 to 0,05 ; $* *=$ significant value for $\mathrm{p}<0.05$; \#Area is distinguished between urban and rural environment considering where children lived. The area of living for two children is unknown.

Source: Authors (2021).

Multivariate analysis showed that overall head lice prevalence in girls was significantly higher than in boys $(54.0 \% \mathrm{vs}$ $\left.35.0 \% ; \mathrm{OR}=2.18 ; \mathrm{F}_{(1)}=11.429 ; \mathrm{p}<0.001\right)$. When considering only the children with nits attached on their hair, the analysis showed that children from the urban School I had a higher probability to harboring nits than children from other schools $(\mathrm{OR}=$ 2.20, School I; OR = 1.51, School II; OR = 1.92 School III-urban; and OR = 1.00 School III-rural; Table 1). Additionally, in the same School I, nine-year-old children had a greater risk of presenting nits $\left(\mathrm{F}_{(10)}=1.920 ; \mathrm{p}=0.027\right)$.

Although there was no statistical difference regarding sex and active infestation $(16.2 \%$ vs $9.4 \% ; \mathrm{OR}=1.86 ; \mathrm{p}=0.083$; Table 1), the multivariate comparison test demonstrated that nine-year-old girls had more probability to present active infestation $\left(F_{(6)}=2.162 ; p=0.046\right)$. Besides, at this age children show to have 4.89 times more risk to be infested with active pediculosis than ten-year-old children, however there was no statistical difference $(\mathrm{p}=0.051$; Table 1$)$.

The vacuum was the best method to detect active infestation, and the prevalence of children with active infestation by this methodology was $9.9 \%$ (35/358), whereas by the comb method was 3.8\% (14/358) and 2.3\% (8/358) with VIMG. Moreover, the vacuum was 11.29 times more efficacious than the comb method to detect mobile lice ( $<<0.001$, Table 2) and was 5.96 times more efficacious than VIMG ( $\mathrm{p}<0.039$, Table 2$)$. In addition, the diagnosis of active infestation through the comb method was 3.7 times more efficacious to diagnose active infestation than VIMG, however there was no statistical difference among these two methods $(\mathrm{p}=0.730$; Table 2$)$.

Table 2. Efficacy of the visual inspection with magnifying glass (VIMG), comb method and vacuum method on the diagnosis of active pediculosis.

\begin{tabular}{lccc}
\hline METHOD & VIMG & & Comb method \\
\cline { 2 - 3 } Comb method & OR (p-value) & & OR (p-value) \\
Vacuum method & $5.70(0.730)$ & - & $11.29(<0.001)$ \\
\hline
\end{tabular}

Notes: VIMG = Visual inspection with a magnifying glass; OR = Odds Ratio test; $p$-value = significant values $\mathrm{p}<0.05$ by the chi-square test.

Source: Authors (2021).

Accuracy, sensitivity and negative predictive value (NPV) of the vacuum method was greater than the comb and VIMG methods (Table 3). Active pediculosis diagnostic accuracy of the vacuum was $96.6 \%$, while comb accuracy was $90.8 \%$ and VIMG accuracy was $89.1 \%$ (Table 3). Vacuum sensitivity was $74.5 \%$, while comb sensitivity was $29.8 \%$ and VIMG was $17.0 \%$ (Table 3). Vacuum NPV was $96.3 \%$, while the others two were $90.4 \%$ and $88.9 \%$, respectively (Table 3 ). Besides the great efficacy, accuracy, sensitivity and NPV, the vacuum method itself detected more than half (55.3\%) of the 47 active infestation cases (26/47), while $14.9 \%$ (7/47) were detected only by the comb method, $10.6 \%$ (5/47) only by VIMG, and the other $19.1 \%$ (9/47) were diagnosed by the vacuum method as well as by one of the other two methods. 
Table 3. Accuracy, sensitivity and negative predictive values from visual inspection with a magnifying glass (VIMG), comb method and vacuum method on the diagnosis of active pediculosis.

\begin{tabular}{lccc}
\hline & VIMG & Comb method & Vacuum method \\
\cline { 2 - 4 } Accuracy & $89.1 \%$ & $90.8 \%$ & $96.6 \%$ \\
Sensitivity & $17.0 \%$ & $29.8 \%$ & $74.5 \%$ \\
NPV & $88.9 \%$ & $90.4 \%$ & $96.3 \%$ \\
\hline
\end{tabular}

Notes: VIMG $=$ Visual inspection with a magnifying glass; NPV = negative predictive value

Source: Authors (2021).

A multivariate analysis of hair characteristics and pediculosis was performed in 346 of the 358 schoolchildren (Table 4). The analysis showed that children with long and wavy/curly hair had a greater risk to have active pediculosis in comparison to children with short and wavy/curly hair $\left(\mathrm{F}_{(2)}=3.680, \mathrm{p}=0.026\right)$. There was no association of hair characteristics with the active infestation cases reported by the VIMG and comb methods (Table 4). Meanwhile, there was an association between the results obtained by the vacuum method and hair length and type $\left(\mathrm{F}_{(2)}=5.001 ; \mathrm{p}=0.007\right)$, in which vacuum was more efficacious to detect active infestation in wavy/curly hair than the other two methods ( $\mathrm{OR}=0.97 \mathrm{VIMG}, \mathrm{OR}=0.86 \mathrm{comb}$ method, and OR $=1.43$ vacuum method; Table 4 ).

Table 4. Active infestation comparison by each of the three methods (visual inspection with a magnifying glass (VIMG), comb method and vacuum method) regarding hair characteristics.

\begin{tabular}{|c|c|c|c|c|c|c|c|c|}
\hline & \multicolumn{2}{|c|}{ Active Infestation } & \multicolumn{2}{|c|}{ VIMG§ } & \multicolumn{2}{|c|}{ Comb method§ } & \multicolumn{2}{|c|}{ Vacuum method } \\
\hline & $\mathrm{n} / \mathrm{N}(\%)$ & OR & $\mathrm{n} / \mathrm{N}(\%)$ & OR & $\mathrm{n} / \mathrm{N}(\%)$ & OR & $\mathrm{n} / \mathrm{N}(\%)$ & OR \\
\hline \multicolumn{9}{|l|}{ LENGHT } \\
\hline Long & 25/146 (17.1) & 2.05 & $5 / 146(3.4)$ & 2.52 & $8 / 146(5.5)$ & 2.69 & $18 / 146(12.3)$ & 1.85 \\
\hline Medium & $8 / 50(16.0)$ & 1.95 & $1 / 50(2.0)$ & 1.48 & $2 / 50(4.0)$ & 1.99 & $6 / 50(12.0)$ & 1.85 \\
\hline Short & $13 / 150(8.7)$ & 1.00 & $2 / 150(1.3)$ & 1.00 & $3 / 150(2.0)$ & 1.00 & $10 / 150(6.7)$ & 1.00 \\
\hline \multicolumn{9}{|l|}{ TYPE } \\
\hline Wavy/Curly & $12 / 89(13.5)$ & 1.02 & $2 / 89(2.3)$ & 0.97 & $3 / 89(3.4)$ & 0.86 & $11 / 89(12.4)$ & 1.43 \\
\hline Straight & $34 / 257(13.2)$ & 1.00 & $6 / 257(2.3)$ & 1.00 & $10 / 257(3.9)$ & 1.00 & $23 / 257(9.0)$ & 1.00 \\
\hline \multicolumn{9}{|l|}{ COLOR } \\
\hline Dark & $40 / 292(13.7)$ & 1.27 & $7 / 292(2.4)$ & $1.30^{*}$ & $13 / 292(4.5)$ & _- & $28 / 292(9.6)$ & 1.00 \\
\hline Light & $6 / 54(11.1)$ & 1.00 & $1 / 54(1.9)$ & 1.00 & $0 / 54(0.0)$ & - & 6/54 (11.1) & 1.65 \\
\hline Total & $46 / 346(13.3)$ & & $8 / 346(2.3)$ & & $13 / 346(3.8)$ & & $34 / 346(9.9)$ & \\
\hline $\begin{array}{l}\text { Notes: } 346 \text { chi } \\
(46 / 346) \text { were } \\
=\text { number of ch } \\
\text { among } \\
\text { §Fisher test wi } \\
\text { Source: Author }\end{array}$ & $\begin{array}{l}\text { n were enrolled } \\
\text { ive; VIMG = Vis } \\
\text { en with active pe } \\
\% \text { confidence in }\end{array}$ & $\begin{array}{l}\text { he co } \\
\text { inspec } \\
\text { losis; } \\
\quad 0\end{array}$ & $\begin{array}{l}\text { son betwee } \\
\text { vith a magn } \\
\text { oint preval }\end{array}$ & $\begin{array}{l}\text { e infe } \\
\text { lass; } \\
\text { r facto }\end{array}$ & $\begin{array}{l}\text { on diagnosis a } \\
\text { number of chi } \\
\text { /n); OR = Od } \\
\text { to }\end{array}$ & $\begin{array}{l}\text { hair } \\
\text { n nur } \\
\text { tio t }\end{array}$ & $\begin{array}{l}\text { acteristics, wh } \\
\text { per hair chara } \\
\text { p-value non- }\end{array}$ & $\begin{array}{l}13.3 \% \\
\text { stic; } n \\
\text { ificant } \\
0.05 \text {; }\end{array}$ \\
\hline
\end{tabular}

\section{Discussion}

The data gathered from this study contribute to a better understanding of active pediculosis diagnostic methodologies and epidemiology. As the overall pediculosis prevalence was higher than in Brazilian northern regions (Devera, 2012; Pilger et 
al., 2008) the study area, within southern Brazil, could be defined as a pediculosis hot spot. However, this higher prevalence could be associated to the vacuum method, a more efficacious methodology.

The present study showed that nine-year-old children from urban areas had a higher risk of presenting nits than those from non-urban areas. Association between urban areas and head lice is unclear; however, children from low-income urban areas had been related to the infestation, as lice control is perceived as too expensive to their families (Willems et al., 2005; Pilger et al., 2008). Additionally, younger children are more affected by pediculosis, mainly because myths that this infestation is a signal of inadequate hygiene may result in shame or low motivation from their parents to seek formal medical assistance and prophylactic measures to control the disease (Jamani et al., 2019; Silva et al., 2008; Gordon, 2007). However, as the child ages and acquires self-care independence, the incidence of infestation seems to decline (Heukelbach et al., 2005; Mendes et al., 2017).

In developing countries there is a misconception that girls are more often infested than boys, as the finding of nits is normally considered a signal of infestation (Silva et al., 2008). Girls have more risk of showing nits as they keep their hair long (Moosazadeh et al., 2015; Borges \& Mendes, 2002). However, when a study focuses on the diagnosis of active infestation, there is no distinction between sex (Birkemoe et al., 2016), as observed in the present study. Moreover, because health professionals have difficulty in detecting mobile forms on the head, active pediculosis can be neglected, which has leading to unnecessary application of anti-louse formulation on nits infested girls (Jamani et al., 2019; Cummings et al., 2018).

Our study is the first to compare the vacuum method with the comb method and the VIMG. Diagnosing pediculosis through visual inspection is challenging but the use of a magnifying glass allows for detection of head injuries and lymphadenopathies in children with longstanding head lice infestation (El-Sayed et al., 2017). Even with three examiners visual inspection seems to be less effective than other methods, like the vacuum on the detection of active infections (Lustosa et al., 2020). In addition, the present study showed that using a magnifying glass had no improvement in the detection of mobile lice (Table 2), likely because it avoids light and can crawl quickly (Cummings et al., 2018). Therefore the VIMG method should be used as a complement favoring a better treatment to pediculosis with associated comorbidity.

In the present study, when using the comb method, it was found a lower occurrence of active infestation than those found in northeastern Brazil (Pilger et al., 2008), central Chile (Neira et al., 2009), and central Argentina (Toloza et al., 2018). Additionally, comb sensitivity was 30\% in comparison to 90\% found in Germany (Jahnke et al. 2009) and Argentina (Toloza et al., 2018). A possible explanation for these differences lay in the choice of using the dry comb method instead of the wet comb. Even though there is no evidence on wet comb being more effective than dry comb (Kurt et al., 2009), the dry combing was chosen in the present study as the procedures were carried out through the winter in some schools and wetting the hair could inhibit children participation.

Moreover, despite the dry comb method being considered four times more effective and twice as fast than the direct visual inspection method (Mumcuoglu et al., 2001; De Maeseneer er al., 2000), the present survey demonstrated that this method can misdiagnose active infestation cases in wavy/curly hair (Table 4). Children with wavy/curly hair suffer from the difficulty in combing their hair with a head lice comb, as it is time-consuming, a tedious process, causes physical pain and damages the hair, and all of these reasons decrease test sensitivity and child acceptance (Mumcuoglu et al., 2020). Thus, neither the VIMG nor the comb method showed to be good choices for the study area.

The vacuum method shows to be the most efficacious in the diagnosis of active infestation, and is also seven times better on the diagnosis of active infestation than direct visual inspection (Lustosa et al. 2020). Vacuum sensitivity was also higher than the other two methods (74.5\%; Table 3) and solely detected 55\% of the active infested children. In addition, its sensitivity could be even higher if the vacuum method did not miss a quarter of the children with active pediculosis. The vacuum probably missed some active infestations because it was the third procedure the child went through and, if she had a mobile lice, it would have been removed at the VIMG and/or at the comb method prior to the vacuum method. 


\section{Final Considerations}

The high sensitivity of the vacuum method in capturing mobile lice suggests that this method could be used not only to the diagnosis but as a treatment strategy in recent infestations, when the number of lice forms are still low, and could avoid the unnecessary use of potentially hazardous anti-louse formulations in children with wavy/curly hair. Moreover, the high prevalence $(13.1 \%)$ of active pediculosis among schoolchildren from the metropolitan region of Curitiba demonstrated the multifactorial character of the disease highlighting the need of educational activities, associated to the correct diagnosis, to clarify the complexity involved with the disease. In accordance with the recent inclusion of pediculosis with "scabies and others ectoparasites" in the WHO's neglected tropical disease portfolio (World Health Organization, 2020) indicates that a regional educative program should be created aiming the detection and control of pediculosis.

Furthermore, other studies should be conducted to assure the efficacy of the vacuum method in the treatment of pediculosis, contributing to diminishing toxic drugs use. In that way, as the vacuum methodology, adapted with a playful activity, shows to be a less stigmatizing procedure, it could reduce infestation outbreaks and improve public health among schoolchildren.

\section{Acknowledgments}

We thank all students and lab technicians for their assistance during part of the study. Moreover, we thank the financial support from UFPR Office for Extension and Culture (PROEC) and by the Brazilian Extension Program for Universities (ProExt). Scholarship from UFPR/Tesouro Nacional and Araucária Foundation (to Lustosa BPR), CAPES (to Haidamak J, Oishi CY, Lima BJFS), PROEC/UFPR (Batista, MO), National Institute of Scholarship Management (INAGBE/Angola) (to Tchivango AT) and National Council of Technological and Scientific Development, Brasilia, Brazil, for fellowship CNPq 312811/2018-7 (Vicente VA).

\section{References}

Birkemoe, T., Lindstedt, H. H., Ottesen, P., Soleng, A., Næss, Ø., \& Rukke, B. A. (2016). Head lice predictors and infestation dynamics among primary school children in Norway. Family Practice, 33(1), 23-29. https://doi.org/10.1093/fampra/cmv081.

Borges, R., \& Mendes, J. (2002). Epidemiological aspects of head lice in children attending day care centres, urban and rural schools in Uberlandia, central Brazil. Memórias Do Instituto Oswaldo Cruz, 97(2), 189-192. https://doi.org/10.1590/S0074-02762002000200007.

Chongsuvivatwong, V. (2018). EpiDisplay: epidemiological data display package (R package version 3.5. 0.1.). https://CRAN.Rproject.org/package=epiDisplay

Cummings, C., Finlay, J. C., \& MacDonald, N. E. (2018). Head lice infestations: A clinical update. Paediatrics \& Child Health, 23(1), e18-e24. https://doi.org/10.1093/pch/pxx165.

Cunha, P. V. da S., Pinto, Z. T., Liberal, E. F., \& Barbosa, J. V. (2008). O discurso dos professores sobre a transmissão de pediculose antes de uma atividade educativa. Journal of Human Growth and Development, 18(3), 298-307.

De Geer, C. (1778). Mémoires pour Servir à l'Histoire des Insectes, vol. 7. Stockholm.

De Maeseneer, J., Blokland, I., Willems, S., Vander Stichele, R., \& Meersschaut, F. (2000). Wet combing versus traditional scalp inspection to detect head lice in schoolchildren: observational study. Bmj, 321(7270), 1187-1188. https://doi.org/10.1136/bmj.321.7270.1187

Devera, R. (2012). Epidemiología de la pediculosis capitis en América Latina. SABER. Revista Multidisciplinaria Del Consejo de Investigación de La Universidad de Oriente, 24(1), 25-36.

El-Sayed, M. M., Toama, M. A., Abdelshafy, A. S., Esawy, A. M., \& El-Naggar, S. A. (2017). Prevalence of pediculosis capitis among primary school students at Sharkia Governorate by using dermoscopy. Egyptian Journal of Dermatology and Venerology, 37(2), 33. http://doi.org/10.4103/ejdv.ejdv_47_16

Gordon, S. C. (2007). Shared vulnerability: a theory of caring for children with persistent head lice. The Journal of School Nursing, 23(5), 283-292. https://doi.org/10.1177/10598405070230050701

Heukelbach, J., Wilcke, T., Winter, B., \& Feldmeier, H. (2005). Epidemiology and morbidity of scabies and pediculosis capitis in resource-poor communities in Brazil. British Journal of Dermatology, 153(1), 150-156. https://doi.org/10.1111/j.1365-2133.2005.06591.x

Jahnke, C., Bauer, E., Hengge, U. R., \& Feldmeier, H. (2009). Accuracy of diagnosis of pediculosis capitis: visual inspection vs wet combing. Archives of Dermatology, 145(3), 309-313. https://doi.org/10.1001/archdermatol.2008.587 
Jamani, S., Rodríguez, C., Rueda, M. M., Matamoros, G., Canales, M., Bearman, G., Stevens, M., \& Sanchez, A. (2019). Head lice infestations in rural Honduras: the need for an integrated approach to control neglected tropical diseases. International Journal of Dermatology, 58(5), 548-556. https://doi.org/10.1111/ijd.14331

Karim, T., Musa, S., Khanum, H., \& Mondal, D. (2015). Occurrence of Pediculus humanus capitis in relation to their personal hygiene and social behaviour among the children in Dhaka City. Bangladesh Journal of Zoology, 43(2), 327-332. https://doi.org/10.3329/bjz.v43i2.27403

Kurt, O., Tabak, T., Kavur, H., Muslu, H., Limoncu, E., Bilaç, C., Balcioğlu, I. C., Kaya, Y., Ozbel, Y., \& Larsen, K. (2009). Comparison of two combs in the detection of head lice in school children. Acta Parasitologica Turcica / Turkish Society for Parasitology, 33(1), 50-53.

Lustosa, B. P. R., Haidamak, J., Oishi, C. Y., Souza, A. B. de, Lima, B. J. F. de S., Reifur, L., Shimada, M. K., Vicente, V. A., Aleixandre, M. A. V., \& Klisiowicz, D. do R. (2020). Vaccuuming method as a successful strategy in the diagnosis of active infestation by Pediculus humanus capitis. Revista Do Instituto de Medicina Tropical de Sao Paulo, 62. https://doi.org/10.1590/s1678-9946202062007

Mendes, G. G., Borges-Moroni, R., Moroni, F. T., \& Mendes, J. (2017). Head lice in school children in Uberlândia, Minas Gerais State, Brazil. Journal of Tropical Pathology, 46(2), 200-208. https://doi.org/10.5216/rpt.v46i2.47572

Moosazadeh, M.., Afshari, M.., Keianian, H., Nezammahalleh, A., \& Enayati, A. A. (2015). Prevalence of Head Lice Infestation and Its Associated Factors among Primary School Students in Iran: A Systematic Review and Meta-analysis. Osong Public Health and Research Perspectives, 6(6), 346-356. https://doi.org/10.1016/j.phrp.2015.10.011

Mumcuoglu, K. Y., Friger, M., Ioffe-Uspensky, I., Ben-Ishai, F., \& Miller, J. (2001). Louse comb versus direct visual examination for the diagnosis of head louse infestations. Pediatric Dermatology, 18(1), 9-12. https://doi.org/10.1046/j.1525-1470.2001.018001009.x

Mumcuoglu, K.Y., Pollack, R.J., Reed, D.L., Barker, S.C., Gordon, S., Toloza, A.C., Picollo, M. I., Taylan-Ozkan, A., Chosidow, O., Habedank, B., Ibarra, J., Meinking, T.L. and Vander Stichele, R.H. (2020), International recommendations for an effective control of head louse infestations. International Journal of Dermatology, 60, 272-280. https://doi.org/10.1111/ijd.15096

Neira, P. E., Molina, L. R., Correa, A. X., Américo Muñoz, N. R., \& Oschilewski, D. E. (2009). Utilidade do pente metálico com dentes microcanaliculados no diagnóstico da pediculose. Anais Brasileiros de Dermatologia, 84(6), 615-621. https://doi.org/10.1590/S0365-05962009000600007

Pilger, D., Khakban, A., Heukelbach, J., \& Feldmeier, H. (2008). Self-diagnosis of active head lice infestation by individuals from an impoverished community: High sensitivity and specificity. Revista Do Instituto de Medicina Tropical de Sao Paulo, 50(2), 121-122. https://doi.org/10.1590/S0036-46652008000200011

Programa das Nações Unidas para o Desenvolvimento (2013). Atlas do desenvolvimento humano no Brasil: árvore do IDHM, Organização das Nações Unidas, Programa das Nações Unidas para o Desenvolvimento. http://www.atlasbrasil.org.br/2013/pt/arvore/municipio/anicuns_go_2010/municipio/penaforte_ce_2010/

Silva, L., Alencar, R. de A., \& Madeira, N. G. (2008). Survey assessment of parental perceptions regarding head lice. International Journal of Dermatology, 47(3), 249-255. https://doi.org/10.1111/j.1365-4632.2008.03570.x

Stevenson, M., Nunes, T., Heuer, C., Marshall, J., Sanchez, J., Thornton, R., Reiczigel, J., Robison-Cox, J., Sebastiani, P., Solymos, P., \& Yoshida, K. (2019) epiR: Tools for the Analysis of Epidemiological Data. R package version 1.0-4. Available from: https://CRAN.R-project.org/package=epiR

Toloza, A. C., Laguna, M. F., Ortega-Insaurralde, I., Vassena, C., \& Risau-Gusman, S. (2018). Insights about head lice transmission from field data and mathematical modeling. Journal of Medical Entomology, 55(4), 929-937. https://doi.org/10.1093/jme/tjy026

Willems, S., Lapeere, H., Haedens, N., Pasteels, I., Naeyaert, J. M., \& De Maeseneer, J. (2005). The importance of socio-economic status and individual characteristics on the prevalence of head lice in schoolchildren. European Journal of Dermatology, 15(5), 387-392.

World Health Organization. (2020). Ending the neglect to attain the Sustainable Development Goals: a road map for neglected tropical diseases 2021-2030. Geneva: World Health Organization. https://apps.who.int/iris/handle/10665/332094 